\title{
Medicine, Non-Malignant Disease
}

National Cancer Institute

\section{Source}

National Cancer Institute. Medicine, Non-Malignant Disease. NCI Thesaurus. Code C19192.

Medicine related to non-malignant disease 